\title{
KEANEKARAGAMAN JENIS JAMUR PADA TANAMAN KOPI (Coffea spp.) DI BANDAR LAMPUNG
}

\section{DIVERSITY OF FUNGI ON COFFEE PLANT (Coffea spp.) IN BANDAR LAMPUNG}

\author{
Melinda Sari ${ }^{1}$, Yulianty ${ }^{1}$, Martha Lulus Lande ${ }^{1}$ \\ ${ }^{1}$ Jurusan Biologi FMIPA, Universitas Lampung \\ e-mail: Melinda.sari@yahoo.com \\ Jurusan Biologi FMIPA Universitas Lampung \\ Jl. Prof.Dr. Soemantri Brojonegoro No. 1, Bandar Lampung, Lampung, Indonesia, 35145
}

\begin{abstract}
Abstrak
Kopi merupakan tanaman tropis yang memiliki nilai ekonomi tinggi, namun rentan terhadap serangan hama dan penyakit, diantaranya jamur. Jamur dapat menghambat pertumbuhan bahkan menyebabkan kematian pada organ tanaman kopi. Penelitian tentang jamur yang terdapat pada tanaman kopi di Bandar Lampung belum banyak dilakukan, sehingga informasi tentang keanekaragamannya sangat terbatas. Penelitian ini dilakukan untuk mengetahui keanekaragaman jamur pada tanaman kopi di Bandar Lampung. Penelitian ini telah dilaksanakan di laboratorium Botani Jurusan Biologi FMIPA Universitas Lampung. Bagian tanaman kopi yang diduga terinfeksi oleh jamur diambil dari beberapa perkebunan kopi di Bandar Lampung. Dari penelitian ditemukan 19 jenis jamur pada tanaman kopi 18 jenis jamur diantaranya merupakan anggota kelas Deuteromycetes dan satu jenis jamur merupakan kelas Ascomycetes. Berdasarkan pada bagian tanaman yang terserang; 8 jenis jamur pada daun, 4 jenis jamur pada batang, 1 jenis jamur pada ranting, 2 jenis jamur pada akar dan 3 jenis jamur pada buah.
\end{abstract}

Kata Kunci: Jamur, Kopi, Bandar Lampung

\section{Abstract}

Coffee is the tropical plant that has high economic value, but are susceptible from pest and diseases, including diseases caused by fungal attack. Fungi can inhibit plant growth and even death to the plant organ affected. Research on fungi that attack coffee plant in Bandar Lampung has not been done, so the information about its diversity is very limited. This study was conducted to determine the diversity of fungi on coffee in Bandar Lampung. Identification of samples was conducted in the Laboratory of Botany Department of Biology FMIPA Unila. Parts of the coffee plants suspected of being infected by fungi taken from several areas in Bandar Lampung. The results of the study found 19 species of fungi that consist of 18 species of fungi are from class Deuteromycetes and one species is belong to Class Ascomycetes. Of the 19 species of fungi were found, eight species obtained on the leaves, four species of rods, one species of twig, two species of root, and three species of fruit.

Key Word: Coffee, Fungi, Bandar Lampung.

\section{PENDAHULUAN}

Bandar Lampung merupakan wilayah pengembangan komoditas kopi dengan luas area $88 \mathrm{Ha}$. Kenaikan produksi kopi diperkirakan 40 persen dari tahun 2009 hingga tahun 2010 atau berkisar 100.000 ton. Produksi kopi pada tahun 2011 meningkat hingga 60 persen (Direktorat Jendral Perkebunan, 2011).

Untuk mempertahankan peningkatkan produksi kopi, perlu dilakukan pengendalian penyakit pada tanaman kopi. Beberapa penyakit yang sering menyerang tanaman kopi adalah penyakit cendawan akar coklat, akar putih, busuk akar, jamur upas, karat daun, bercak daun dan bercak daun alga (Widodo dan Sutiyoso, 2009). Gejala serangan jamur pada tanaman kopi berupa bercak-bercak pada daun, busuk pada buah dan akar, jelaga pada ranting dan daun yang dapat menghambat pertumbuhan (Sukamto, 1998). 
Sebelum dilakukan pengendalian penyakit yang disebabkan oleh jamur tersebut perlu diketahui terlebih dahulu jenis-jenis jamur yang menyerang tanaman kopi, Berdasarkan Indeks Tanaman inang di Indonesia telah ditemukan 45 jenis jamur pada tanaman kopi. Namun pada saat ini belum banyak penelitian tentang keanekaragaman jamur pada kopi terutama di Bandar Lampung. Tujuan penelitian ini adalah untuk mengetahui jenis-jenis jamur pada tanaman kopi di Bandar Lampung. Hasil penelitian ini diharapkan dapat memberikan informasi mengenai keanekaragaman jamur yang terdapat pada tanaman kopi sehingga dapat digunakan sebagai dasar untuk pengendalian penyakit pada tanaman kopi.

\section{BAHAN dan METODE}

Penelitian ini telah dilaksanakan dari bulan Juni sampai dengan Agustus 2012. Bagian-bagian tanaman kopi yang terserang jamur dikumpulkan dari beberapa wilayah di Bandar lampung dan diamati di Laboratorium Botani Jurusan Biologi FMIPA Universitas Lampung.

Bagian-bagian tanaman kopi, akar, batang, daun, buah dan ranting yang diduga terinfeksi jamur dikumpulkan dari beberapa wilayah perkebunan kopi di Bandar Lampung yaitu, Kemiling, Taman Kupu-Kupu Gita Persada, Batu Putu, dan Kedaton Bandar lampung. Pengumpulan sampel tidak dilakukan sekaligus tetapi diselingi dengan pemeriksaan mikroskopis di laboratorium. Pemeriksaan secara mikroskopis dilakukan dengan cara mencukil sedikit koloni jamur dengan jarum pentul atau pinset runcing, lalu koloni jamur diletakkan pada gelas objek yang telah diberi sedikit laktofenol dan gliserin, dan ditutup dengan gelas penutup. Preparat ini kemudian diamati di bawah mikroskop dan dilakukan pengukuran panjang dan lebar konidia dan konidiofornya. Identifikasi jamur dilakukan dengan berpedoman pada Buku identifikasi jamur yaitu Ellis (1976), Ellis (1971), Booth (1971), dan Barnett \& Hunter (1998).

\section{HASIL dan PEMBAHASAN}

Dari hasil penelitian diketahui terdapat 19 jenis jamur yang menyerang tanaman kopi di Bandar Lampung (Tabel 1). Sembilan jenis jamur yang ditemukan pada daun, yaitu Ascochyta coffeae, Botryodiplodia theobromae, Curvularia robusta, C. intermedia, Dactylaria dioscorea, Drechslera sorgycola, Corynespora cassiicola, Pithomyces maydicus, dan Scolecobasidium gyrocarpii. Jamur yang ditemukan pada batang ada empat je- nis, yaitu Sporidesmium coffeicola, Sporidesmium bambusae, Cladosporium tennuissimum dan Helminthosphaeria calvariarum. Satu jenis jamur yang ditemukan pada ranting yaitu Drechslera sp. Dua jenis jamur yang ditemukan pada akar yaitu Micronectriella nivalis dan Botryodiplodia theobromae, dan Tiga jenis jamur ditemukan pada buah, yaitu Pithomyces sp., Fusarium sulphureum dan Fusarium sp.

Tabel 1. Jenis-Jenis Jamur pada tanaman kopi

\begin{tabular}{|c|c|}
\hline Marga & Jenis Jamur \\
\hline $\begin{array}{rc}\text { DEUTEROMYCETES } \\
\text { A. } \begin{array}{c}\text { Hypomycetes } \\
\text { Cladosporium }\end{array} \\
\end{array}$ & Cladosporium tennuissimum \\
\hline Corynespora & Corynespora cassicola \\
\hline Curvularia & $\begin{array}{l}\text { Curvularia robusta } \\
\text { Curvularia intermedia }\end{array}$ \\
\hline Dactylaria & Dactylaria dioscorea \\
\hline Drechslera & $\begin{array}{l}\text { Drechslera sp. } \\
\text { Drechslera sorgycola }\end{array}$ \\
\hline Fusarium & $\begin{array}{l}\text { Fusarium sp. } \\
\text { Fusarium sulphureum }\end{array}$ \\
\hline Helminthospheria & Helminthospharia calvariarum \\
\hline Pithomyces & $\begin{array}{l}\text { Pithomyces sp. } \\
\text { Pithomyces maydicus }\end{array}$ \\
\hline Scolecobasidium & Scolecobasidium gyrocarpii \\
\hline Sporidesmium & $\begin{array}{l}\text { Sporidesmium coffeicola } \\
\text { Sporidesmium bambusae }\end{array}$ \\
\hline $\begin{array}{l}\text { B. Coelomycetes } \\
\text { Ascochyta }\end{array}$ & Ascochyta coffeae \\
\hline Botryodiplodia & $\begin{array}{l}\text { Botryodiplodia theobromae (Daun) } \\
\text { Botryodiplodia theobromae (Akar) }\end{array}$ \\
\hline $\begin{array}{l}\text { ASCOMYCETES } \\
\text { Micronectriella }\end{array}$ & Micronectriella nivalis \\
\hline
\end{tabular}

Dari kesembilan belas jenis jamur yang ditemukan, 18 diantaranya merupakan anggota kelas khusus Deuteromycetes, dan satu jenis jamur dari kelas Ascomycetes. Jenis jamur yang sering ditemukan pada tanaman kopi yaitu dari marga Drechslera, Pithomyces, Curvularia, Sporidesmium dan Fusarium, masing-masing 2 jenis.

Jamur dari marga Fusarium apabila tidak ada inang dapat hidup di dalam tanah. Penyebaran jamur Fusarium sangat luas dan menyerang pada beberapa tanaman karena dapat tersebar dengan perantara angin, air tanah dan atau terbawa oleh alat pertanian (Doolittle, 1961). Jamur dari marga Curvularia, Drechlera dan Sporidesmium banyak ditemukan pada tanaman kopi karena selain memiliki sebaran yang luas, jamur ini mudah menyebar dengan spora melalui hembusan angin atau percikan air (Domsch, 1980). 
Pithomyces merupakan cendawan yang tersebar secara alami. Di dunia, Pithomyces terdapat lebih dari 40 jenis, Jamur ini biasanya menyerang bagian daun yang sudah mati dari 50 jenis tanaman yang berbeda-beda (Domsch, 1993).

Jenis jamur Botryodiplodia theobromae ditemukan pada dua bagian tanaman kopi yaitu daun dan akar. B. theobromae memiliki kisaran inang yang luas dan kemampuan untuk menyerang berbagai jaringan tanaman, seperti akar, batang, daun, buah dan ranting dengan gejala yang beragam bergantung jenis inangnya (Nurhasanah, 2012).

\section{KESIMPULAN}

Di temukan 19 jenis jamur pada tanaman kopi di sekitar Bandar Lampung, yang terdiri dari 8 jenis jamur pada daun, 4 jenis pada batang, 1 jenis pada ranting, 2 jenis pada akar dan 3 jenis pada buah.

\section{DAFTAR PUSTAKA}

Barnett, H. L., and Hunter B.B. 1998. Ilustrated Genera of Imperfecti Fungi. Burgess Publishing Company. Minneapolis.

Booth, C. 1971. The Genus Fusarium. Commonwealth Mycological Institute. England.
Direktorat Jendral Perkebunan. 2011. Statistik Perkebunan. Departemen Pertanian. Jakarta.

Domsch, K.H., Gams, W. and Anderson, T.H. 1980. Compedium of Soil Fungi. Academic Press. London

Domsch, K.H., Gams, W. and Anderson, T.H. 1993. Compedium of Soil Fungi. Vol. I. IHWVerlag, Germany.

Doolittle, S.P, Taylor, A. L. and Danielson,. 1961.

Tomato Diseases and Their Control. Agricultural Research. United State Department of Agriculture.

Ellis, M.B. 1971. Dematiaceous Hypomy-cetes X. Commonwealth Mycologist Institute. Kew.

Ellis, M.B. 1976. More Dematiaceous Hyphomycetes. Principal Mycologist Commonwealth Mycologist Institute, Kew.

Nurhasanah. 2012. Karakterisasi Cendawan Botryodiplodia theobromae dan Rhizoctonia solani dari Berbagai Tanaman Inang Berdasarkan Morfologi dan Pola RAPD-PCR. IPB. Bogor.

Sukamto. S, 1998. Pengelolaan Penyakit Tanaman kopi. Kumpulan Materi Pelatihan PengeIolaan Organisme Pengganggu Tanaman Kopi. Jakarta

Widodo dan Sutiyoso Y. 2009. Hama \& Penyakit Tanaman. Deteksi Dini \& Penanggulangan. PT. Trubus Swadaya. 


\section{Lampiran 1. Jenis-jenis jamur pada tanaman kopi di Bandar Lampung}

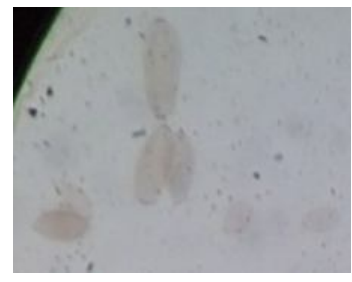

Cladosporium tennuissimum

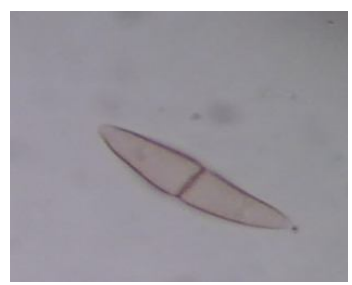

Dactylaria dioscorea

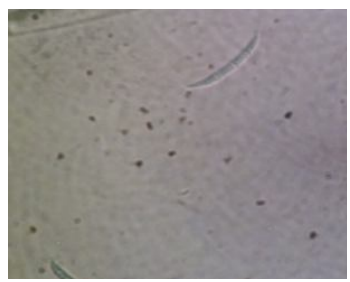

Fusarium sulphureum

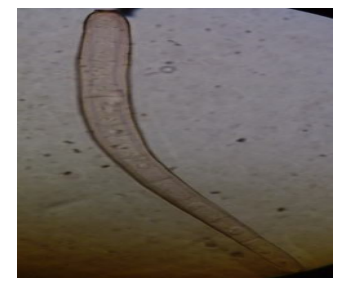

Corynespora cassiicola

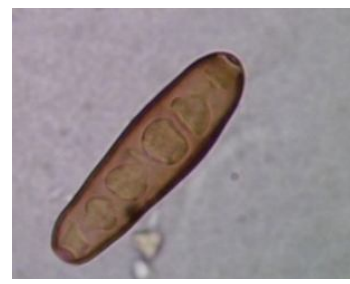

Drechslera sp.

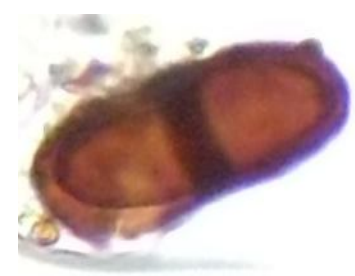

Helminthospharia clavariarum

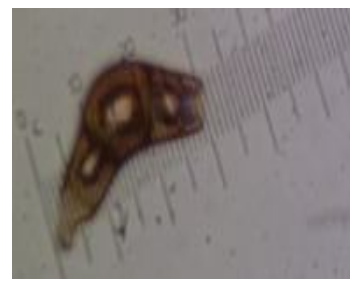

Curvularia robusta

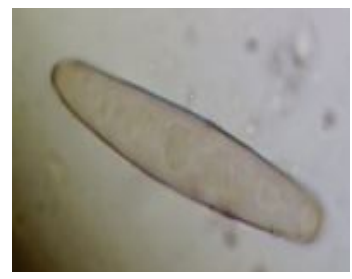

Drechslera sorghycola

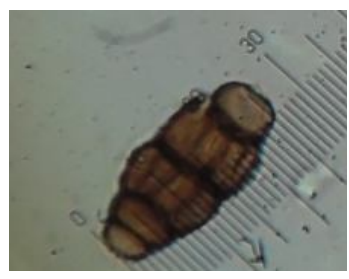

Pithomyces sp.

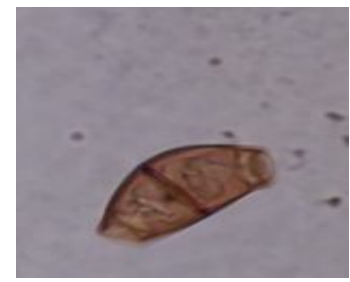

Curvularia intermedia

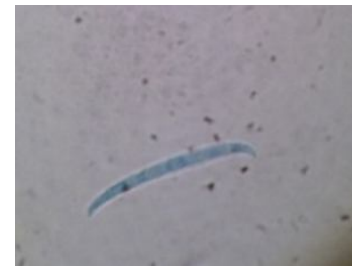

Fusarium sp.

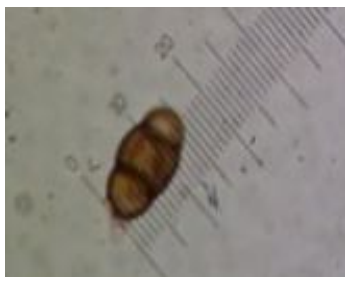

Pithomyces maydicus

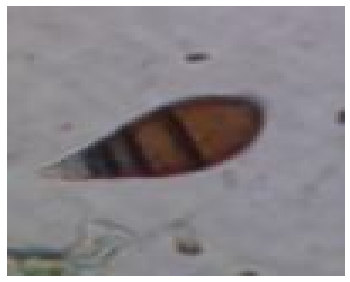

Sporidesmium coffeicola

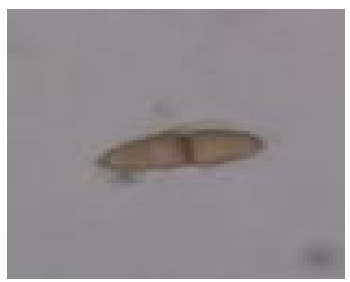

Aschocyta coffeae

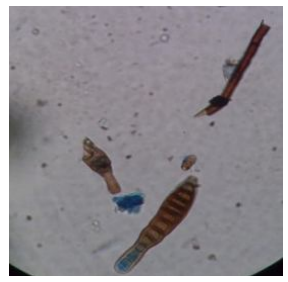

Sporidesmium bambusae

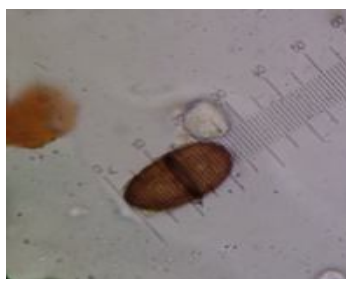

Botryodiplodia theobromae

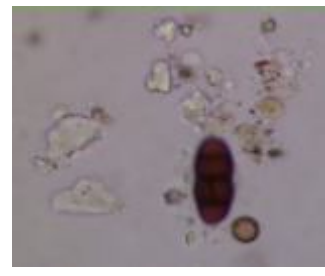

Scolecobasidium gyrocarpi

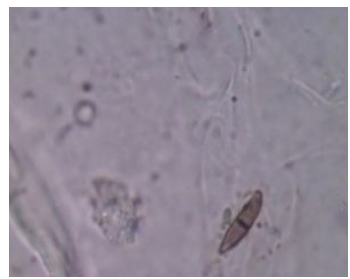

Micronectriella nivalis 